\title{
2. National urban policies in a federal system: the case of Germany
}

Hubert Heinelt and Karsten Zimmermann

\section{INTRODUCTION}

This contribution seeks to demonstrate that national urban policies in Germany are only to a limited degree the result of coherent policy design. National urban policies do exist but indicate a broad (in the sense of non-specific) understanding of 'urban' (towns, cities and metropolises, but also villages). National government has no clear profile or preference in terms of designing urban policies which address the needs of big cities. Two sets of arguments are involved in key policy drivers which support or prevent the emergence of national urban policies. The first involves the federal structure of the political system and the distribution of competencies between the federal level and the states (Länder) in Germany. A consensual national priority for cities is prevented by the fact that only some of the German Länder are highly urbanised (North Rhine-Westphalia and the three city-states in particular), while others show a more balanced structure of urban and rural areas (Lower Saxony, Bavaria, Saxony). The second involves the considerable levels of local autonomy enjoyed by the two tiers of local government (municipalities and counties form the local government tiers). Their autonomy is written into the constitution, including the right of municipalities to levy their own taxes.

\subsection{Current Local Government System}

The German local government system is an essential element of German federalism. This is due, on the one hand, to the federal structure of the political system and the distribution of tasks and competencies between the federal level and the states (Länder) in Germany. Three out of 16 states (Berlin, Bremen and Hamburg) are city-states. In these city-states, the state and local government levels coincide in an urban context in terms of their related tasks and competencies. Hence, these three city-states differ in terms of institutions from their national counterparts (county-free cities such as Munich, Stuttgart 
or Frankfurt am Main), as they can form their own urban policies or play an influential role in the second chamber of federal government (Bundesrat) (Heinelt and Zimmermann 2016).

The German local government system is composed of two tiers: counties and municipalities (Kuhlmann and Wollmann 2014, p. 79). The counties (Landkreise) represent the municipalities within them and administer a range of services and policies on behalf of these municipalities (public transport, maintenance of local streets and school buildings, health services and some environmental policies). Other forms of inter-municipal cooperation are widely used for waste management, sewage disposal, local development and public transport. Bigger cities usually have the status of a county-free city, that is, they are a county and municipality at the same time, which gives them a stronger role. This applies to cities such as Munich, Frankfurt am Main, Leipzig, Stuttgart and Dortmund. In total there are 295 counties, 107 county-free cities and about 12000 municipalities in Germany.

Each state has its own municipal code, which defines the functional and territorial profile of municipalities, the mandate of the mayor and the councillors, the ways in which they are elected, the option for local referenda and many aspects of municipal administration. However, since the 1990 s a process of converging local statutes has taken place, and one result is the introduction of directly elected mayors in all states (Wollmann 2004). Nevertheless, the functional and territorial profiles of municipalities still differ substantially from state to state (see Egner 2013). This variety is a result of Article 28 of the German Basic Law (Grundgesetz), which stipulates the right to local self-government and ensures an independent source of income for local government (currently a share of the business tax). This underlines the dual character of municipalities, as entities of local self-government and the lowest administrative tier with mandatory and delegated tasks.

Everyday implementation of any kind of urban policy is the result of shared and fused policy making between the different levels of government. In particular, there is federal legislation for urban planning and building regulation, which defines instruments, options and limits. Policies and funding options relevant to cities take the form of joint or federal schemes (largely for urban regeneration and urban renewal, but also for transport policy).

However, the German Basic Law clearly stipulates that federal government cannot determine whether, to what extent or how a policy is carried out at the urban level. In the German federal system, implementing joint funding schemes such as housing or urban regeneration is the remit of states (Länder). National urban policy initiatives and amending relevant laws are the result of cooperative federalism, where the second chamber at the federal level (Bundesrat) plays an essential role. Every national urban regeneration programme requires consent from the federal states, and consensus between these 
states and the federal government. This consent is occasionally jeopardised by what has been described as a 'joint-decision trap' (Scharpf 1988).

As a result, urban problems are mainly dealt with at state level rather than federal (national) level. Each state has its own rules determining the distribution of tasks and competences between local and state governments, as well as the transfer of funding from state to local government. Although some national initiatives have been established in recent years, such as Nationale Stadtentwicklungspolitik (National Urban Development Policy; see below), there is neither a coherent national strategy for urban development nor an explicit national urban policy.

Within this federal system, which has both joint and separate competencies, cities are not simply the recipients of funding or passive policy-takers (Heinelt and Terizakis 2020; Zimmermann, Boghrat and Weber 2015). As noted above, cities, and county-free cities in particular, have considerable status which is written into the constitution and allows for discretion in developing and implementing policies. They can develop their own policies and define their own priorities for urban development, and national and sub-national legislation gives them room to manoeuvre (Zimmermann, Boghrat and Weber 2015). They mix federal and EU funding schemes with their own revenue and use federal frameworks to design discrete policy solutions. The result is a nationwide variety of local policies, where one of the main limitations involves budgetary constraints.

\subsection{Current Challenges for Urban Areas}

The last Urban Development Report 2016 (Bundesregierung 2016) of the German federal government raised a series of issues and challenges for urban areas. These were demographic changes and shrinkage, climate change and climate adaptation, digitisation and social cohesion. Note that this report is a document of the federal government; the states may have different priorities but usually don't publish urban agendas or reports on urban problems.

Currently, the most pressing issues calling for nationwide interventions are affordable housing, the costs involved in measures for integrating migrants and refugees, air pollution (largely due to the diesel scandal ${ }^{1}$ ) and maintenance of school buildings. ${ }^{2}$ In addition, climate change and climate adaptation are a major concern, and are often addressed within sectoral policy programmes (energy policy) or as part of urban regeneration programmes (see below) (Zimmermann, Boghrat and Weber 2015). Budget problems in municipalities are an ongoing issue. However, not all states have supported sporadic initiatives by Social Democrat ministers at federal level to develop a national debt-relief programme for cities with heavy debts. 
In the last decade, a veritable housing crisis has emerged in the big urban agglomerations. Lack of affordable housing for sectors other than low-income groups was one the most relevant issues in national, sub-national and local election campaigns (in Frankfurt, Berlin and Munich, for example). There are two reasons for this:

1. Considerable population growth and a lack of building activity in city-regions such as Munich, Frankfurt, Stuttgart and Hamburg (but also in smaller university towns) have meant that house prices and rents are rising. Low- and medium-income households face difficulties in finding appropriate housing, or are forced to move out to suburban or even peri-urban areas.

2. For decades, there was a joined-up funding programme for social housing between federal government and the federal states, but in 2006, following the reform of German federalism, the federal government transferred this task completely to the states. The result was that social housing policy came more or less to a standstill, but even before this, subsidies within the joint social housing programme had been decreasing for years (Egner and Grabietz 2018).

The current federal government's coalition treaty states that sufficient subsidies will be transferred to the Länder and further measures will be taken. However, how this transfer should take place is currently under discussion, as it would require a change in the Basic Law. The total amount of funding should nevertheless be 2 billion euros in 2020/21 (CDU, CSU and SPD 2018, p. 110).

Construction and school-building maintenance are other local activities which already have the financial support of the federal government. Local government is responsible for this task, but local policy priorities and severe budgetary problems mean that many school buildings in German cities are in a bad condition. Although the situation differs considerably between rich and poor states, and between rich and poor municipalities, a new funding scheme for infrastructure was opened in 2015, followed by one for school buildings in 2017. This fund (Kommunalinvestitionsförderungsfonds), managed by a state bank (KfW), provides 7 billion euros for the two programmes (Kommunalinvestitionsförderungsgesetz 2017).

Air pollution control and air-quality management are issues where the role of federal government is not quite as clear, but they are currently highly relevant. Air pollution control and planning follow EU regulations, and implementation falls within the remit of the states. However, the 'diesel scandal' from 2017 onwards called for action from the federal government. This was mainly for political reasons, as the automotive industry is of national relevance. Moreover, permission for new cars is granted by a national agency 
which is also in charge of controls and is partially responsible for prosecuting car manufacturers. In 2018, several courts decided that a ban on diesel cars was the only measure which could ensure EU regulation targets were met. As several German cities and hundreds of thousands of commuters are affected, federal government has gradually taken the initiative, establishing an ad hoc programme known as 'Clean Air 2017-2020'. It is supported by 1 billion euros, and directly addresses cities.

Integrating migrants and refugees is another local task that has been calling for federal financial aid. The massive influx of refugees and asylum seekers in 2015 meant that local governments at the time were not in a position to fulfil these obligations, which not only include payments for subsistence (including housing), but also language courses, childcare or vocational training. Federal government released 6.6 billion euros to the states in 2017, much of which benefited municipalities, but not all states forwarded the subsidies in full to the local level (Bundesregierung 2018). Federal government will continue to support municipalities until 2021 (CDU, CSU and SPD 2018).

\section{EVOLUTION OF NATIONAL URBAN POLICIES}

National urban policies have evolved over the past 50 years in the form of joined-up federal programmes and political initiatives focusing on specific urban issues. This pattern emerged in the late 1960s/early 1970s when an economic crisis, and deindustrialisation in particular, culminated in an urban crisis. This involved two mutually reinforcing elements: a) inner-city areas and working-class neighbourhoods showed strong signs of decay and suffered from a lack of investment; b) a lack of fiscal capacity and tools for urban renewal. German cities had experienced reconstruction in the immediate post-war period, but there was no profiled policy for urban regeneration. Mayors and state governments requested a national response, and as a consequence, the urban crisis became part of the national political agenda. This was partly because of legislation, as the German building code and planning law did not provide appropriate legal instruments for urban regeneration. As a result, a new national funding scheme called urban development assistance (Städtebauförderung) came into effect in 1971, accompanied by a special law on urban regeneration. This was the first instance of a joined-up programme where federal government and the states supported cities in tackling physical problems in distressed areas. Following a similar pattern of joint funding, other programmes were established to support municipalities in the realms of transport and social housing. An essential element of these programmes was the (re) distribution of huge amounts of funding. The involvement of federal government in match-funding local activities was new, and was only possible because reforms to the fiscal relationships between the federal level and the states 
came into effect in the late 1960s. However, implementing these programmes fell within the remit of the 16 states and the local level. Federal government provided the resources without intervening too heavily in the details.

The evolution of these federal aid programmes can be considered part of the extension of the German post-war welfare state. Providing decent urban environments and appropriate housing at low cost was one of the objectives of German welfare policy. Even today, the federal government's participation in these programmes is justified by one of the fundamental goals of the German welfare state: the provision of equivalent living conditions throughout the territory.

This national urban policy was more a combination of sectoral programmes for housing, urban renewal and transport than a coherent urban agenda, and it did not change much over time. In this form of negotiated or cooperative federalism, the funds available depend on the budget situation of federal government, and are renegotiated between the states and federal government each year. In terms of instruments and policy priorities, urban development assistance turned out to be a very flexible programme. New issues such as sustainable urban development in the 1980s and 1990s, social cohesion and energy efficiency, as well as climate adaptation in more recent times, could be easily incorporated in terms of goals and instruments.

The mechanism for this programme is stable, although the available sums may differ according to the priorities of federal government and the available budget. However, there is still no clear profile or coherent agenda for national urban policy. There are a number of reports, but the government has never adopted a document which could be considered a national urban agenda. An initiative known as the National Urban Development Policy (Nationale Stadtentwicklungspolitik), established in the mid-2000s, has made few inroads in this capacity. This initiative started as a joint undertaking of the then federal Ministry for Transport and Urban Development, two local government associations (Städtetag and Städte- und Gemeindebund) and the standing group of ministers, the latter being in charge of urban regeneration policies at state and federal level.

It is a voluntary measure under the leadership of the German federal government, and offers some funding opportunities. The programme began in 2007 and finances a number of different types of pilot project (such as initiatives for adapting to climate change and energy efficiency in old neighbourhoods). Up to 50 million euros per year were made available for the period between 2014 and 2017; in 2015, this figure rose to 100 million euros. ${ }^{3}$ Apart from providing funding, however, the programme does not involve any institutional changes.

In 2005, federal government decided to inform the parliament every four years about the state of cities in a report on urban development (Bundesregierung 2016). Since then, three reports have been published (2008, 
2012, 2016). The reports are not national urban agendas but summaries of all the programmes and intiatives federal government offers to cities. The reports also describe some of the challenges and urban problematiques currently under debate. The last report also included a clear and timely commitment to the Sustainable Development Goals and UN-Habitat (Bundesregierung 2016, p. 29). In 2015, an interministerial working group on sustainable urban development was established (ibid.). Though only bringing together federal ministries, this measure demonstrates that federal government has some ambition with regard to sustainable urban development.

There is still neither a coherent national strategy for urban development nor an explicit national urban policy. Instead, there are only a few fragmented strategies and urban policies at federal level, alongside specific strategies and urban policies in the individual federal states. It should be noted that the above-mentioned national policies do not discriminate between cities, towns and villages, but usually refer to the legal concept of 'commune' (Kommune or Gemeinde), a general term for an institution of local self-government. Even some of the laws of the early 1970s, which were designed to support cities in solving problems of growth and inner-city regeneration, had the word 'community' in their title (e.g. the Gemeindeverkehrsfinanzierungsgesetz from 1971, a law that was expected to support cities in solving the problem of increasing car-based mobility).

\section{ACTORS: WHO IS DRIVING THE CHANGES?}

The main German political parties do not have an explicit urban agenda, and in the past urban issues were not usually an issue in national electoral campaigns, at least compared to other pressing issues such as pensions, economic development, security or energy policy. The situation changed in recent years when, against the background of the above-mentioned 'housing crises', housing policy and the role played in it by local government became part of the agenda (see Egner and Grabietz 2018). However, at federal level, coalition governments have shown varying interest in urban policies in the last few decades. These differences will be outlined below in terms of the relevant ministries and ministers, as the different ministries responsible for urban issues at federal and state level are clearly key players in making national urban policy (Heinelt and Zimmermann 2016).

However, this in itself is over-simplifying the issue. It is important to take into account that different ministries (and their agencies) ${ }^{4}$ in both tiers of upper-level government are responsible for, or involved in, different urban issues. Ministries of the Interior in the individual federal states have a formal responsibility for the legal supervision of local governments. However, when it comes to developing specific urban policies or programmes, the relevant 
ministries involved in each issue play a key role. The same is true for the federal level. One example is the white paper 'Urban Green', published in 2017 by the Federal Ministry of the Environment (BMUB 2017). The white paper is a collection of all the arguments in favour of green infrastructure in cities and describes the measures and steps to be taken to improve accessibility to high-quality green spaces in urban neighbourhoods. The Ministry of the Interior, Building and Community, which is in charge of urban development assistance, took up the initiative and incorporated 'Urban Green' into the urban regeneration funding scheme.

Between 1998 and 2013, the Federal Ministry for Transport, Building and Urban Development (Bundesministerium für Verkehr, Bau und Stadtentwicklung) was made formally responsible for urban issues. Although several Social Democrats were heads of this ministry between 1998 and 2009, and a Christian Democrat between 2009 and 2013, it focused mainly on transport, largely because this is where most of its budget and personnel were allocated (Egner et al. 2004, pp. 149-153).

However, a coalition cabinet formed by Social Democrats and the Greens between 1998 and 2005 increased resources for urban regeneration, and the programme 'Social City' (briefly mentioned above and described in more detail below) was introduced in 1999. Furthermore, the Federal Minister for Transport, Building and Urban Development in the 'grand coalition cabinet', formed between 2005 and 2009 by Christian Democrats (CDU/CSU) and Social Democrats (SPD), was the former mayor of Leipzig, Wolfgang Tiefensee. During this period, urban topics became important for federal government, and it was no coincidence that the EU Charter of Sustainable Urban Development was signed in Leipzig in 2007 during the German presidency of the EU. In addition, the National Urban Development Policy was born in an attempt to define the goals and principles of a national urban policy. Since then, the National Urban Development Policy has been a joint initiative of federal government, the states and the cities. It defines good urban policy as being sustainable, integrated and inclusive. In 2012, the agenda was renewed by publishing a memorandum on 'urban energies'. Apart from some funding for pilot projects and research, instruments for implementing the agenda involve the joint financing schemes described above.

The change in federal government in 2009 brought a significant shift. Between 2009 and 2013, the government was formed at federal level by a coalition of Christian Democrats (CDU/CSU) and Liberals (FDP). The Ministry for Transport, Building and Urban Development was led during this time by Peter Ramsauer from the Bavarian CSU. He made a sharp cut in resources for urban regeneration, and in particular for the sub-programme 'Social City'.

From 2013 to 2017, Germany was once again governed at federal level by a 'grand coalition cabinet'. During this period, a Social Democrat (Barbara 
Hendricks) was head of the ministry responsible for most urban issues, which was renamed the Federal Ministry for the Environment, Nature Conservation and Nuclear Safety. Once again, there was an increase in the resources available for social urban regeneration.

After the election in September 2017, a 'grand coalition cabinet' was formed once again, and most urban issues became the responsibility of the Ministry of the Interior, Building and Community ${ }^{5}$ led by Horst Seehofer, the then chairman of the Bavarian CSU.

The process of making national urban policy in this period is complicated by the broad spectrum of tasks falling under the remit of this ministry which is responsible for urban issues at federal level. Concrete policy making depends heavily on processes linked to the national 'problem-agenda', dominated by certain 'advocacy coalitions' formed by different governmental actors (from different territorial levels) and non-governmental organisations. The way these groups jostle for position can sometimes produce explosive results.

Furthermore, it can be concluded that the SPD is inclined to do more for cities than the conservatives (housing and debt release). The Greens are probably the only party with a specific interest in urban policies (renewable energy, sustainable transport and migration policy). This can probably be explained by the fact that the 'green-alternative' urban middle class is a prominent supporter of this party. In fact, quite a few Green politicians belong to this urban milieu. However, even the Green Party rarely publishes specific urban policy agendas, and the other parties are not sufficiently engaged.

Despite the presence of the main parties, the most influential actors in terms of their stake in the matter are the three different local government associations. They all act on a national basis (addressing federal government): ${ }^{6}$

- The Städtetag represents the big cities, which are usually county-free cities. Hence, there is a partial overlap of interest with the Landkreistag (the association of counties, see below) because both groups have similar responsibilities (i.e. schools, social policies, public hospitals, public transport). In addition, the Städtetag is more engaged in big-city topics such as the international competitiveness of urban centres and social cohesion (against a background of international migration and social segregation within urban centres). These are the main challenges for bigger cities, and in particular there is an argument that there should be financial compensation for certain big-city infrastructure financed by the bigger cities, as this also serves people living in the surrounding counties. The president of the Städtetag is usually a mayor who is well known to the public, and who tries to bring together the voices of public opinion and ensure the cities are heard. 
- Smaller municipalities - usually those belonging to a county - are members of the Städte- und Gemeindebund, which has to cover a broad spectrum of concerns due to the diverse situation of its members (shrinkage, infrastructure provision in sparsely populated areas, broadband access, etc.).

- Finally, all German counties (the second tier of local government; see Egner and Heinelt 2011) are members of the German Landkreistag, the national association of counties. This is mainly concerned with issues such as running hospitals, and particularly provision for unemployment and other such needs which are not fully covered by federal welfare schemes.

These associations partly serve as lobby organisations and are usually consulted by federal government even though they are not constitutional organs. The three local government associations have regional branches in the Länder, as the Länder, being the level of implementation, are of equal importance as the national arena.

Unlike in France, local politicians (mayors) rarely hold influential positions. Cumul de mandat is uncommon, if not forbidden, in Germany, and local politicians do not usually play a role in national politics.

As noted at the beginning, the federal states, which maintain a strong institutional position in the field of urban policies, can follow their own specific goals in terms of urban policy in their respective territories. However, with respect to national policies their aim is fairly straightforward and general. On the one hand, they try to secure their authority over local government. On the other hand, they act as strongholds for local self-government in that they try to avoid financial burdens for local government resulting from national policies. However, the motivation for this is not only to ensure that they shift tasks and financial burdens to the local level, but also to avoid financial problems for local government which force them to ask 'their' federal government for financial support (usually involving a change in fiscal equalisation schemes within individual federal states). If the federal states agree on a (usually joint) national urban policy or programme, they are keen to look for redistributive effects between the federal states, and between the federal level and the federal state level.

\subsection{What Is the Role and Influence of the EU?}

From the 1990s onwards, EU urban policy has offered over the years a stable set of instruments, principles and funding opportunities for cities (Atkinson and Zimmermann 2016). As these initiatives have largely been part of Cohesion Policy, other policies such as sustainable urban mobility (SUMP) and smart city initiatives can also be considered EU urban policy, as can environmental regulation, which is less frequently considered urban policy but 
which has huge impacts on local politics and planning (air pollution control, noise reduction, Seveso III directive). In Germany's case, EU urban policy was not particularly relevant until the early 2000s when, with the advent of EU programmes such as URBAN, area-based initiatives were introduced throughout Germany (Zimmermann 2008). The integrated approach was innovative and triggered substantial changes in the way policies were designed for disadvantaged neighbourhoods. It is important to note that the URBAN approach found resonance in federal states such as North Rhine-Westphalia, Bremen, Hamburg and Berlin, which were instrumental in co-designing initiatives before the federal government established a nationwide programme ('Soziale Stadt'). This makes it an interesting case of national policy diffusion (Häussermann 2006).

\subsection{Why Should National Government Intervene?}

Although it can hardly be considered a universal rule, federal government tends to intervene in principle when a group of federal states submit a claim for financial help, often in agreement with the three local government associations. Examples include the recent turn in social housing policy, or compensation for the costs of integrating refugees. Federal government has rarely set up initiatives without a request from the states. The National Urban Development Policy introduced by Minister Tiefensee is an exception to this rule. The reason for this could be the path-dependency inscribed in the constitution. The authors of the constitution assumed that the division of tasks and fiscal relationships in German federalism, along with the strong status of local self-government, would mean that federal financial aid for cities would be exceptional. In fact, the relevant articles (104b and 91a) of the Basic Law (the German constitution) state that federal aid for municipalities (and the states) is possible during a nationwide economic crisis or for balancing economic disparities throughout Germany. These rules still apply, and they define the role of federal government, although urban development assistance has become a permanent task over the years.

However, as will become clear later, national government needed cities as 'agents' in order to implement policies and programmes tackling climate change (energy efficiency, renewables, etc.) (Zimmermann, Boghrat and Weber 2015). This constitutes a slightly different type of national urban policy. It is supplementary to the old 'help for cities in need' and has become 'cities as agents of co-implementation' for national climate-policy objectives. 


\section{SPECIFIC POLICIES}

\subsection{Urban Regeneration and Urban Development Assistance}

Urban development assistance continues to be the most relevant building block in what remains an implicit national urban policy (Altrock 2012). Established in times of urban crisis in the early 1970s, the programme turned out to be a flexible and adaptable instrument for supporting cities in solving problems of urban renewal. For cities, the programme is a reliable and necessary source of funding. While defining goals and policy issues is the result of negotiations between the states and federal government, implementing these programmes is the remit of the states and the local level, and federal government allocates a large proportion of its resources within an agreed policy framework. The overall objective of this programme is to facilitate intervention in areas with functional deficits such as lack of public infrastructure and green spaces or substandard housing. In addition, the programme allows for measures in the realm of heritage conservation. In terms of eligibility, the way the programme is regulated makes broad participation from cities of all sizes a possibility. In other words, although there is a social deprivation component in the distribution of the funds, the programme is not restricted to a few cities which are most in need.

Over the years, several new components have been added to this joined-up federal policy. One example of this evolutionary development is the programme 'Social City' (Gemeinschaftsinitiative Soziale Stadt), launched in 1999 (Häussermann 2006). The programme was an initiative of the states and of federal government, based on the existing scheme of joint financing for urban regeneration. The aim of the initiative was to overcome sectorally fragmented attempts to solve complex problems in deprived urban neighbourhoods. The previous urban regeneration policy had been considered inadequate because it was very strict in the sense that only measures for physical renewal could be financed, and no investments could be made in social infrastructure or economic development. Some federal states introduced programmes of this kind before 1999 and continued with profiled complementary policies (North Rhine-Westphalia, Hamburg, Bremen, Berlin). Since 1999, the amount and regulation of funding for this programme has been renegotiated each year between the states and federal government. However, some core elements of the programme have remained stable over the years, specifically the emphasis on integrated solutions to solve social problems in deprived urban neighbourhoods, and the requirement that individual projects have to be match-funded by the federal government, the state and the participating city. In theory, each 
level has to contribute one-third of the overall costs, but the cities' share is often partly covered by state governments.

Between 1999 and 2013, 617 areas in 378 municipalities benefited from this programme. The federal government's annual contribution was 51.1 million euros in 1999, and reached 110 million in 2006 (BMUB 2014). Following a change in government and the appointment of a new minister (see section 3 ), the federal contribution dropped to 28.5 million in 2011, and extra funding for pilot projects introduced in 2006 was stopped. In 2014, the new Social Democrat minister in the grand coalition raised the contribution from 40 million euros in 2013 to 150 million euros (ibid.). This illustrates that an integrated approach to urban regeneration is well established, but that its fortunes depend on political fluctuations. The 'Social City' programme was, at least in part, heavily influenced by the EU's URBAN initiative (Häussermann 2006).

In a rather similar way, shrinking cities became an issue at national level in the 2000s. Being a topic already in the 1990s, the issue of shrinking cities moved higher on the agenda, particularly in the eastern part of the Federal Republic (in the territory of the former German Democratic Republic), due to the migration of young people from the east to the west (or even south or south-west) of the country. Shrinkage in eastern German towns was also the result of a stagnating demographic development that happened all over Germany (Müller and Siedentop 2004). Against this background, the federal government launched a programme for the renewal of cities in Eastern Germany (Stadtumbau Ost) in 2002 (Kabisch, Bernt and Peter 2004). Initially, the programme financed the demolition of vacant buildings in order to stabilise housing markets and enable 'sustainable' upgrading and stabilisation of urban neighbourhoods. The federal government was strongly supported by the governments of the East German states, because they were unable to finance a programme such as this on their own. As in the case of the 'Social City' programme, the federal government, the federal states and the participating cities were required to match-fund the initiative and to adopt an integrated approach to urban renewal. In other words, cities have to present an integrated concept for urban development (Integriertes Stadtentwicklungskonzept) in order to take an active part in the programme. In total, 2.7 billion euros were spent on this programme between 2002 and $2013 .^{7}$

Obviously, the financially weak states in Eastern Germany needed financial support from the federal level in order to carry out their part in this programme. However, demographic changes and shrinking cities became increasingly a nationwide problem. The programme 'City Renewal - East' was extended to the rest of Germany in 2004 under the name 'City Renewal - West' (Stadtumbau West), and now more than 443 West German cities are participating. The programme 'City Renewal - West' also requires an integrated 
concept for urban development, as well as match-funding between the federal government, the federal states and the participating cities.

Measures and tools for urban development assistance have also played a significant role in the 'turnaround in energy use' (Energiewende) in Germany. Due to changes in the definition of functional deficits, which are the prerequisite for funding, urban development assistance can now also be used to refurbish houses in terms of insulation, energy efficiency and energy provision. Unlike the other programmes (shrinking cities, Social City, housing, urban renewal) which directly address local problems, the federal government's energy policy seeks to instrumentalise an existing scheme to fulfil national policy targets (reduction of $\mathrm{CO}_{2}$ emissions).

In short, in recent decades, the federal government has often reacted to urban problems by working together with the states to adapt the general urban tool of an implicit national urban policy (urban development assistance), in order to help cities or to implement national policy goals. The latter is very clear in the example of the energy and climate policy.

\subsection{Reduction of Land Consumption - Recent Changes to the Federal Building Act}

Land-use planning is another example of an indirect intervention by federal government into local politics, based on a nationally defined sustainability target. In 2002, the federal government published the German Goals for Sustainability. These included a target of reducing land consumption significantly from ca. 129 ha per day in 2002 to 30 ha per day by 2020 . However, the federal government is not allowed to prescribe binding quantitative targets for the states or municipalities, as spatial planning falls within the competence of the states. One way to implement the national sustainability goals involved changing the Federal Building Act with the consent of the states. In fact, changes to the Federal Building Act in 2006 and 2013 gave priority to inner-city development (reuse of brownfield sites) by making it easier to obtain planning and building permission in inner-city areas. These measures were accompanied by an amendment to Article 1 of the Building Act, which now includes a sentence giving priority to 'Innenentwicklung' (development of the built-up area of an inner-city).

The impact of this measure is not clear. Unlike the UK, where national planning guidance stipulates that 60 per cent of new housing construction should take place on brownfield sites, the law gives instruments to municipalities but does not define quantitative targets for cities to meet. In addition, restrictions for greenfield development are not too strong.

A more recent development is the 2016 amendment to the Federal Building Act, which introduced 'Urbane Gebiete' (urban areas) as a new category for 
local zoning plans. This new category allows building permission to be granted for residential houses in mixed-use zones (commercial areas in particular), which indicates a partial end to the principles of strict separation of functions. The measure was taken by federal government in response to the increasing shortage of affordable housing in big cities. There are no data yet in terms of how successful the initiative is, but hopes that this measure will significantly change the urban housing-market situation are far too optimistic.

These two examples show that federal government defines nationwide policy goals or principles for certain sectors of urban development (affordable housing, land consumption, etc.), but that implementation is cumbersome in reality, as local land-use planning operates at arm's length from federal government.

\subsection{Local Government as part of the German Welfare State - the Case of Labour-Market Policy}

The most recent major labour-market reform in Germany, which came into force in January 2005, can be characterised as indirectly related to urban policies because it reduced the financial burdens of local government. It did this by shifting the responsibility for paying benefits to unemployed people from the county and (county-free) cities to the federal level. However, the main aim of this reform was a fundamental policy change in terms of the German welfare state. In total, expenditure in the counties and big (county-free) cities for people in need (which is not reimbursed by federal government) decreased from 8.44 billion euros in 2004 to 676.3 million euros in 2006 (Federal Office for Statistics 2007).

In terms of urban policies, it is interesting to note that this reform only obtained the necessary consent of the second chamber at federal level (Bundesrat) after a compromise was agreed between the federal government and the majority of the governments of the federal states. This compromise involved who was responsible for labour-market policy for the long-term unemployed, and therefore related to the role of counties and big (county-free) cities in the German welfare state. While the responsibility for labour-market policy for the short-term unemployed (fewer than 12 months) remained within the remit of the Federal Employment Agency and its local branches, ${ }^{8}$ responsibility for the long-term unemployed is now shared in a number of different ways between the Federal Employment Agency and the counties (Landkreise) or the big (county-exempt) cities. However, job centres were established to coordinate the services and payments of the local branches of the Federal 
Employment Agency and local government. ${ }^{9}$ These job centres are organised either as

- ' joint agencies' (Arbeitsgemeinschaften/ARGE), later renamed 'joint facilities' (gemeinsame Einrichtungen; see below), of a local employment agency and the local government department responsible, or

- what is known as 'Optionskommune'. These are Landkreise and larger municipalities which provide all services on their own and are responsible for all payments (including expenditure for unemployment assistance/ Arbeitslosengeld II for which they are reimbursed by federal government). They are called 'Optionskommunen' because Landkreise and larger municipalities had the opportunity to 'opt' for this organisational structure (Konle-Seidl, Eichhorst and Grienberger-Zingerle 2007).

In December 2007, the German Supreme Court decided that the 'joint agencies' (Arbeitsgemeinschaften) were not in line with the German constitution because 'mixing the administration' of levels of government could blur political accountability. Furthermore, it was argued by the German Supreme Court that 'mixed administration' by local government and the Federal Employment Agency could bring into question the constitutionally guaranteed right of local self-government. In June 2010, a federal law was passed allowing 'joint facilities' (gemeinsame Einrichtungen) instead of 'joint agencies', and it increased the number of 'Optionskommunen'. In 2018, there were 303 'joint facilities' and 104 'Optionskommunen'. ${ }^{10}$

The growing involvement of local government in the challenging field of labour-market policy demonstrates their vital role in social policy in Germany. However, the example also demonstrates the strength of the idea of local self-government in Germany.

\section{CONCLUSION}

In terms of the distinction between implicit or explicit and direct or indirect national urban policies, the German model clearly presents a mixture of all four types. Based on the institutional setting (federalism and local self-government), the default approach is indirect and implicit. Federal government provides resources, sometimes in an instrumental form as an incentive to change local policy practices or as a temporary funding scheme for sectoral policy (e.g. energy, social policies, mobility, urban green), though these resources are usually only tacked onto the general capacity of local governments to solve urban problems. In addition, provision of these resources is under the control of the states. 
Urban development assistance is an exception to this, as it is a direct and explicit place-based policy for urban regeneration. In recent years, there has been a clear attempt to integrate place-based and people-centred policies.

Occasionally, national policy interventions can be observed which directly address urban problems (integration of refugees, affordable housing, mobility in the context of the diesel scandal), but even in these exceptional cases national government does not define binding targets or standards. The mechanism largely involves funding. Energy policy and reducing land consumption are examples of the federal government's limited capacity to fulfil national policy targets through national urban policy. Energy and climate change are notable exceptions, but again, the success of some German cities in this policy area is based on local initiatives which make intensive use of the available funding mechanisms and planning instruments.

The current form of national urban policies in Germany is the result of a system of veto-players in German federalism, and state governments are clearly the gate keepers. In terms of general reflections on urban policies in Germany, it is worth noting that programmes for city renewal are a result of package deals between the federal states and the federal government. These package deals are typical of policy making in the German multi-level system, where a 'joint-decision trap' can only be avoided with the agreement of the federal states. From the point of view of local governments, stronger national policy on urban issues would ultimately be a mixed blessing. They welcome more resources but fear more direct control, particularly in terms of binding targets, and this position finds support with the states.

\section{NOTES}

1. The so-called diesel scandal began in September 2015, when US authorities discovered that car manufacturer VW had manipulated a considerable number of diesel engines in order to meet exhaust-threshold values. This also happened in Germany where cities were struggling to meet the objectives of EU air-quality regulation. Hence, one of the measures discussed involved a ban on diesel cars, but no level of government was in favour of this.

2. This chapter was written before the COVID-19 pandemic.

3. Figures are taken from: https://www.nationale-stadtentwicklungspolitik.de/ (accessed 04.03.2020).

4. One of these agencies is the former Federal Agency for Housing and Spatial Planning (Bundesanstalt für Bauwesen und Raumordung), now called the Federal Institute of Housing, Urban and Spatial Research (Bundesinstitut für Bau-, Stadtund Raumforschung).

5. The official German name for the ministry is 'Bundesministerium des Innern, für Bau und Heimat'. On the ministry's website, this name is translated into English as 'Ministry of the Interior, Building and Community'. 
6. It should be mentioned that there is a strong lobby for the rural parts of Germany, in particular in Bavaria and Lower Saxony, but also in North Rhine-Westphalia and Baden-Württemberg.

7. http://www.staedtebaufoerderung.info/StBauF/DE/Programm/StadtumbauWest/ stadtumbau_west_node.html (accessed 14.02.2016).

8. In Germany, unemployed people can claim earnings-related unemployment benefit for a maximum of one year, provided they have paid social security contributions for at least two years. Unemployed people over 50 can claim for a maximum of two years, provided they have paid social-security contributions for at least five years.

9. Unemployed people who are not or who are no longer eligible for earnings-related unemployment benefits funded by social-security contributions can claim means-tested unemployment assistance (Arbeitslosengeld II). This flat-rate benefit (in 2018, 416 euros for a single person, and each partner in a household receives less) is funded by the federal government through tax income and is paid out either by the local branches of the Federal Employment Agency or an 'Optionskommune'. Local branches of the Federal Employment Agency also offer services such as job placement and occupational guidance for this group of (usually long-term) unemployed. In addition, Landkreise and larger municipalities which do not belong to a Landkreis are in charge of additional payments, such as housing payments, and social services.

10. See https://statistik.arbeitsagentur.de/Navigation/Statistik/Grundlagen/Regionale -Gliederungen/Gebiets struktur-Traeger-Grundsicherung-Nav.html (accessed 19.01.2021).

\section{REFERENCES}

Altrock, Uwe (2012), 'Reurbanisierung und Stadtentwicklungspolitik - städtebauliche Programme und Instrumente', in K. Brake and G. Herfert (eds), Reurbanisierung, Materialität und Diskurs in Deutschland, Wiesbaden: VS-Verlag, pp. 180-196.

Atkinson, Rob and Karsten Zimmermann (2016), 'Cohesion policy and cities: an ambivalent relationship', in Simona Piattoni and Laura Polverari (eds), Handbook on Cohesion Policy in the EU, Cheltenham, UK and Northampton, MA, USA: Edward Elgar Publishing, pp. 413-426.

BMUB - Federal Ministry for the Environment (2014), Statusbericht Soziale Stadt 2009-2014, Berlin.

BMUB - Federal Ministry for the Environment (2017), Weißbuch Stadtgrün Grün in der Stadt - Für eine lebenswerte Zukunft, Berlin.

Bundesregierung (2016), Stadtentwicklungsbericht 2016, Berlin.

Bundesregierung (2018), 'Bericht der Bundesregierung über Maßnahmen des Bundes zur Unterstützung von Ländern und Kommunen im Bereich der Flüchtlingsund Integrationskosten und die Mittelverwendung durch die Länder im Jahr 2017', accessed 18 May 2018 at https://www.bundesfinanzministerium.de/ Content/DE/Standardartikel/Themen/Schlaglichter/Fluechtlingshilfe/18-05-30 -fluechtlingskosten-bericht.pdf?blob=publicationFile \&v $=4$.

CDU, CSU and SPD (2018), Coalition Treaty. Ein neuer Aufbruch für Europa. Eine neue Dynamik für Deutschland. Ein neuer Zusammenhalt für unser Land. Koalitionsvertrag zwischen CDU, CSU und SPD. 19. Legislaturperiode. 
Egner, Björn (2013), 'Stellung und Funktion der Räte im Bundesländervergleich', in Björn Egner, Max-Christopher Krapp and Hubert Heinelt (eds), Das deutsche Gemeinderatsmitglied. Problemsichten - Einstellungen - Rollenverständnis, Wiesbaden: VS Verlag für Sozialwissenschaften, pp. 17-56.

Egner, Björn, Nikolaos Georgakis, Hubert Heinelt and Reinhard Bartholomäi (2004), Wohnungspolitik in Deutschland. Positionen, Akteure, Instrumente, Darmstadt: Schader-Stiftung.

Egner, Björn and Katharina J. Grabietz (2018), 'In search of determinants for quoted housing rents: empirical evidence from major German cities', Urban Research and Practice, 11 (4), 460-477.

Egner, Björn and Hubert Heinelt (2011), 'Germany', in Hubert Heinelt and Xavier Bertrana (eds), The Second Tier of Local Government in Europe: Provinces, Counties, Départements and Landkreise in Comparison, London and New York: Routledge, pp. 106-125.

Federal Office for Statistics (Statistisches Bundesamt) (2007), Wirtschaft und Statistik, No. 12, Wiesbaden: Statistisches Bundesamt.

Häussermann, Hartmut (2006), "The National "Social City Program": findings from the midterm evaluation, German Politics and Society, 24 (4), SPECIAL ISSUE: Social Integration in the New Berlin (Winter 2006), pp. 145-163.

Heinelt, Hubert and Terizakis Georgios (2020), 'Innovative cities: how to explain differences between cities? An answer based on an interpretive approach', Urban Research and Practice, DOI: 10.1080/17535069.2020.1723032.

Heinelt, Hubert and Karsten Zimmermann (2016), 'Cities in the multi-level system of German federalism', in Alistair Cole and Renaud Payre (eds), Cities as Political Objects: Historical Evolution, Analytical Categorisations and Institutional Challenges of Metropolitanisation, Cheltenham, UK and Northampton, MA, USA: Edward Elgar Publishing, pp. 156-174.

Kabisch, Sigrun, Matthias Bernt and Andres Peter (2004), Stadtumbau unter Schrumpfungsbedingungen. Eine sozialwissenschaftliche Fallstudie, Wiesbaden: VS Verlag für Sozialwissenschaften.

Kommunalinvestitionsförderungsgesetz - KinvFG (Gesetz zur Förderung von Investitionen finanzschwacher Kommunen) (2017), Berlin.

Konle-Seidl, Regina, Werner Eichhorst and Maria Grienberger-Zingerle (2007), 'Activation policies in Germany. From status protection to basic income support', IAB Discussion Paper No. 6, Nürnberg: IAB.

Kuhlmann, Sabine and Hellmut Wollmann (2014), Introduction to Comparative Public Administration: Administrative Systems and Reforms in Europe, Cheltenham, UK and Northampton, MA, USA: Edward Elgar Publishing.

Müller, Bernhard and Stefan Siedentop (2004), 'Growth and shrinkage in Germany trends, perspectives and challenges for spatial planning and development', German Journal of Urban Studies, 44 (1), 1-23, accessed 29 March 2010 at http://www.difu .de/node/6053.

Scharpf, Fritz W. (1988), 'The joint-decision trap: lessons from German federalism and European integration', Public Administration, 66 (3), 239-278.

Wollmann, Hellmut (2004), 'The two waves of territorial reform of local government in Germany', in John Migrana (ed.), Redrawing Local Government Boundaries: An International Study of Politics, Procedures, and Decisions, West Mall: UBC, pp. 106-129.

Zimmermann, Karsten (2008), 'Cities for growth, jobs, and cohesion. Die implizite Stadtpolitik der EU', in Hubert Heinelt and Angelika Vetter (eds), Aktuelle Fragen 
der Stadtforschung zu Beginn des 21. Jahrhunderts, Wiesbaden: VS-Verlag, pp. 79-102.

Zimmermann, Karsten, Jasmin Boghrat and Meike Weber (2015), 'The epistemologies of local climate change policies in Germany', Urban Research and Practice, 8 (3), 303-318. 